\title{
The Role of Corporate Governance in Reducing the Negative Effect of Earnings Management
}

\author{
Nopphon Tangjitprom ${ }^{1}$ \\ ${ }^{1}$ National Institute of Development Administration \& Assumption University, Bangkok, Thailand \\ Correspondence: Nopphon Tangjitprom, National Institute of Development Administration \& Assumption \\ University, Bangkok, Thailand. Tel: 66-8-5815-6177. E-mail: tnopphon@gmail.com
}

Received: December 21, 2012

Accepted: January 31, $2013 \quad$ Online Published: February 26, 2013

doi:10.5539/ijef.v5n3p213

URL: http://dx.doi.org/10.5539/ijef.v5n3p213

\begin{abstract}
This paper aims to examine the role of corporate governance in reducing the negative effect of earnings management. The accounting data for U.S. firms during 2002-2010 were collected from WorldScope database and the corporate governance data were from ASSET4, which is an affiliate of Thomson Reuter. Earnings management can be harmful to firm value if it arises from managerial opportunism, whereas it can also be beneficial if managers intend to convey some information about future earnings or reduce the volatility of reported earnings. The empirical evidence has shown that earnings management has a negative effect on firm value. However, the negative effect of earnings management is neutralized by the role of corporate governance, which helps to reduce managerial opportunism. Firms with a lower CG score face the negative effect of earnings management, whereas firms with a higher CG score face a less-negative effect from earnings management. In other words, managerial opportunism with earnings management is lower in good-governance firms. Therefore, corporate governance provides a crucial role in reducing the negative effect of earnings management.
\end{abstract}

Keywords: earnings management, corporate governance, accruals

\section{Introduction}

Earnings Management usually refers to the efforts of firm managers or executives in manipulating the earning figures in financial reporting. Even though these activities have complied with regulations, these activities can arise from managerial opportunism to take advantage of compensation plans (Healy, 1985; Baker, Collins, and Reitenga, 2003; Bregstresser and Philipon, 2006; Kuang, 2008). For example, managers can overstate the reported profit in order to demonstrate the firm's outperformance and obtain incentive payments such as bonuses or understate the earnings to reduce the current share price in order to obtain more benefits from the employee stock options plan. However, some may argue that managers can use earnings management techniques to communicate or convey certain information (Dutta and Gigler, 2002) and to smooth the earnings to reduce its volatility (Magrath and Weld, 2002).

Therefore, earnings management can be both beneficial and harmful to firm value based on how managers employ. There is no simplified way to determine which component of earnings management is harmful or beneficial. However, if there were a mechanism that mitigated managerial opportunism, it would be helpful in reducing harmful earnings management. In this paper, I propose the Corporate Governance mechanism as the useful tool to restrain the opportunistic behaviors of managers that may deteriorate firm value.

Corporate Governance can act as a mechanism to reduce managerial opportunism. Firms with poor corporate governance are more vulnerable to managerial opportunism, and earnings management will be harmful for the firm's value. Meanwhile,, firms with good corporate governance can mitigate these problems, and earnings management will be less harmful or even beneficial for firm value.

The empirical evidence based on U.S. firms supports the above argument. In general, earnings management is negative for firm value. However, after including the effect of corporate governance, this negative relationship becomes neutral. In other words, firms with a lower CG score face the significantly negative effect of earnings management, whereas firms the negative effect of higher CG firms is not significant at the convention level. Therefore, corporate governance provides a crucial role in reducing the negative effect of earnings management.

The outline of this paper is as follows; Section 2 provides a discussion of earnings management and corporate 
governance in the literature; Section 3 discusses the data and methodology; Section 4 discusses the empirical evidence and statistical testing; and Section 5 is the conclusion of the study.

\section{Previous Studies and Hypothesis Development}

Earnings management usually refers to the efforts of firm managers in manipulating earnings reporting. In general, this earnings management is perceived as negative because it may stem from managerial opportunism. Managers use their discretion in earnings management to expropriate private benefit, for example, to get more benefits from their compensation (Healy, 1985; Baker, Collins, and Reitenga, 2003; Bregstresser and Philipon, 2006; Kuang, 2008).

Meanwhile, some studies have pointed out that earnings management is not actually destructive for firms. If the accounting rules are too restrictive, it will discourage the potential benefits of earnings management as a way for managers to communicate trustful forecasting (Dutta and Gigler, 2002). Magrath and Weld (2002) have proposed the idea that managers can use earning management to reduce earnings volatility. This could be beneficial for firm value, as it can help to reduce the risk perceived by investors. Therefore, earnings management may not be destructive for firm value but be consistent with firm value maximization principal.

Earnings management can be both beneficial and negative for firm value. Even though it is not easy to classify which earnings management is beneficial or negative, it is proposed here that if there exists a mechanism that will help to reduce managerial opportunism in terms of expropriating private benefits from firm value, that mechanism should be able to discourage negative earnings management but not discourage beneficial ones. Therefore, the effect of earnings management should be less negative (or more positive) if such a mechanism existed. Corporate governance mechanism that included how shareholder rights are protected should be that mechanism to reduce managerial opportunism.

Jensen and Meckling (1976) have discussed the agency problem in the firm, as managers can consume more perquisites for their private benefit as the expenses of firm if they hold a smaller fraction of ownership in that firm. With the separation of ownership and control, managerial decisions may not follow the firm value maximization principal, as they do not share the wealth with shareholders. Therefore, an effective controlling mechanism such as corporate governance is essentially required (Fama and Jensen, 1983). La Porta et al. (2000) have discussed the notion that the legal investor protections act like external corporate governance to protect outside shareholders (or minority sharedholers) from the expropriation of private benefits by controlling shareholders.

Gomper, Ishii, and Metrick (2003) developed the G-index (Governance Index) based on firm provisions concerning shareholder rights. They found that the firm with weaker shareholder rights will have lower value, measured by the Tobin Q ratio, compared to the firm with stronger shareholder rights. Johnson et al. (2000) studied corporate governance and managerial expropriation during the Asian financial crisis and found that firms in the countries with weaker corporate governance and shareholder rights protection could face more problems related to the managerial expropriation of private benefits.

There has been a number of studies about the role of corporate governance and investor protection in reducing the level of earnings management. Cornett, McNutt, and Tehranian (2009) have studied the corporate governance mechanism and the level of earnings management. Board independence can reduce earnings management because managers cannot influence the board entirely, whereas performance pays can motivate managers to manipulate earnings reporting in order to obtain higher compensation. Wang, Sheu, and Chung (2011) have shown evidence that the level of earnings management was reduced after the implementation of Sarbanes-Oxley Act. Additionally, Hazarika, Karpoff and Nahata (2012) showed evidence that the number of CEO-forced turnovers were positively related to the level of earnings management. This implies the role of the board of directors in preventing aggressive earnings management before there are external consequences.

Leuz at al. (2003) used country-level analysis to show that the aggregate earnings management level is lower in the country with stronger investor protection. Investor protection is based on investor rights and legal enforcement based on La Porta et al. (1998). Defond, Hung, and Trezevant (2007) have shown that earnings announcement is more informative in the country with stronger investor protection.

Based on the above previous studies, it can be seen that earnings management is more likely to be negative for firm value. However, if there is a mechanism such as corporate governance that helps to reduce managerial opportunism, such a mechanism should also be able to discourage negative earnings management. Therefore, the earnings management for a firm with good governance should be less negative (or even positive) than a firm with poor governance. The main research hypothesis is as follows. 
Research Hypothesis: The effect of earnings management on firm value is less negative for the firm with better corporate governance compared to the firm with lower corporate governance.

\section{Data and Methodology}

The data used in this research include all firms traded on the New York Stock Exchange (NYSE) or NASDAQ during 2002-2010. The accounting data were from the WorldScope Database. The Corporate Governance Score was provided by ASSET4, an affiliate of Thomson Reuters, that provides Environmental, Social, and Governance (ESG) data for worldwide firms. The firms whose information as not available in WorldScope or Asset 4 were excluded from the analysis. Finally, there were 5,153 firm-year observations included in the analysis.

First, the relationship between firm value and earning management will be examined. Firm value was measured by Tobin's Q, which is the ratio between the market value of a firm and the book value of a firm. In other words, Tobin's $Q$ is the market value of a firm scaled down by its book value. More value of this ratio can be interpreted as the firm creating more value added to its book value. Earning management consist of the absolute accruals scaled down by operating cash flows, which is one component of aggregate earnings management measurements based on Leuz et al. (2003). The accruals are calculated by

$$
\text { Accruals }_{i}=\left(\Delta C A_{i}-\Delta \text { Cash }_{i}\right)-\left(\Delta C L_{i}-\Delta S T D_{i}-\Delta T P_{i}\right)-D E P_{i}
$$

where $C A$ is the total current assets and Cash represents total cash and equivalents. $C L$ is total current liabilities, $S T D$ is total short-term debts, $T P$ is total taxes payable, and $D E P$ is total depreciation expenses.

The effect of earnings management to firm value is examined based on the following regression model.

$$
\begin{gathered}
F V_{i}=\beta_{0}+\beta_{1} E M_{i t}+\sum_{j=1}^{m} \gamma_{j} \text { CONTROL }_{i t}+\varepsilon_{i t} \\
F V_{i}=\beta_{0}+\beta_{1} E M_{i t}+\gamma_{1} D R_{i t}+\gamma_{2} \text { SIZE }_{i t}+\gamma_{3} G R O W T H_{i t}+\varepsilon_{i t}
\end{gathered}
$$

where $F V$ is the value of the firm i at time t, which is measured by Tobin's $\mathrm{Q}$ ratio or the ratio between the market value of the firm and its book value. $E M$ is the earnings management measurement, which is the absolute accruals from equation 1 scaled down by operating cash flow. CONTROL is a set of control variables, which are $D R$, SIZE and GROWTH, in the analysis. $D R$ is the firm's debt ratio representing the leverage or capital structure policy. SIZE is the firm size measured by the logarithm of total assets. GROWTH is the firm's growth rate of total assets.

According to equation 2, the effect of Corporate Governance is included as follows.

$$
F V_{i}=\beta_{0}+\beta_{1} E M_{i t}+\beta_{2} E M_{i t} \times C G_{i t}+\sum_{j=1}^{m} \gamma_{j} C O N T R O L_{i t}+\varepsilon_{i t}
$$

where $C G$ is the Corporate Governance Score from ASSET4. The interaction effect between earnings management and corporate governance is expected to be positive. If, the coefficient of interaction term $\left(\beta_{2}\right)$ is significantly positive, it means that the effect of earnings management on firm value for the firms with a higher CG score is less negative (or even become positive) than for firms with a lower CG score.

In general, investors may not be concerned about the level of firm corporate governance as a continuous measurement. They usually perceive firms in terms of good or poor governance. Therefore, another way to examine the effect of $C G$ on the relationship between firm value and earnings management is to categorize all firms based on the CG score. Each firm is classified into two groups based on the median. Firms having a CG score above the median are named high-CG or good-governance firms, whereas firms with a CG score lower than median are classified as low-CG or poor-governance firms.

$$
F V_{i}=\beta_{0}+\beta_{1} E M_{i t}+\beta_{2} E M_{i t} \times D_{H I G H}+\sum_{j=1}^{m} \gamma_{j} C O N T R O L_{i t}+\varepsilon_{i t}
$$

where $D H I G H$ is the dummy variable that equals one if that firm has a CG score above the median in that fiscal year or zero otherwise. The coefficient of the interaction term $\left(\beta_{2}\right)$ can be interpreted as the difference between high-CG firms (CG score higher than median) and low-CG firms (CG score lower than median) in the relationship between their firm value and earnings management. This coefficient is expected to be positive to show that the effect of earnings management is less negative (or even positive) for high-CG firms. 


\section{Analysis and Results}

Table 1 reports on the data for the firms in the sample during the period of analysis. The ratio between market value and book value of firm assets or Tobin $\mathrm{Q}$ was around 2 times during the analysis period. This market value ratio was lowest in 2008 as a result of the credit crunch from the subprime crisis. The earnings management measures, which are the accounting accruals scaled down by operating cash flow, varied. It is interesting that this figure was highest during 2008, which was the period when the U.S. economy most suffered from the crisis. Moreover, U.S. firms, in average, use debt at around $60 \%$ of their total assets. The average annual growth rate of their assets is $13.69 \%$. Before 2008 , the growth rates increased year-by-year and have drop dramatically to lower than $10 \%$ during $2008-2009$.

Table 1. Descriptive statistics on sample firms

\begin{tabular}{ccccc}
\hline Year & Tobin Q & $\begin{array}{c}\text { Earnings } \\
\text { Management }\end{array}$ & $\begin{array}{c}\text { Debt } \\
\text { Ratio }\end{array}$ & $\begin{array}{c}\text { Asset } \\
\text { Growth (\%) }\end{array}$ \\
\hline 2002 & 2.0103 & 1.8145 & 0.5865 & 12.7783 \\
2003 & 2.2452 & 1.2301 & 0.5793 & 15.3588 \\
2004 & 2.3249 & 0.8201 & 0.5801 & 16.0270 \\
2005 & 2.2649 & 0.9714 & 0.5730 & 16.9119 \\
2006 & 2.1804 & 0.8518 & 0.5954 & 17.4062 \\
2007 & 2.1372 & 1.3431 & 0.6040 & 20.9936 \\
2008 & 1.4783 & 2.5777 & 0.6288 & 9.0601 \\
2009 & 1.7590 & 1.0765 & 0.5887 & 8.6067 \\
2010 & 1.9426 & 1.6249 & 0.5837 & 12.6520 \\
\hline Overall & 1.9718 & 1.4189 & 0.5933 & 13.6944 \\
\hline
\end{tabular}

The effect of earning management and firm value is reported in table 2. In model 1, earnings management is a sole regressor and the coefficient is negative and significant at the convention level. This means that the effect of earnings management on firm value, in general, was negative. Model 2 includes a set of control variables that may have an impact on firm value. This cannot alter the earlier result, as the coefficient of earnings management is still significantly negative. Model 3 includes the interaction term between earnings management and corporate governance score to show the effect of corporate governance on the relationship between earnings management and firm value. The coefficient of the interaction term was positive and significant at the convention level, as expected. It can then be interpreted that the effect of earning managements is usually negative. However, the firm with a higher CG score will have a less negative effect of earnings management. In other words, for firms with a higher CG score, earnings management will deteriorate the firm value less than those with a lower CG score.

Table 2. The effect of earnings management to firm value

\begin{tabular}{|c|c|c|c|}
\hline Coefficient & Model 1 & Model 2 & Model 3 \\
\hline \multirow[t]{2}{*}{ Constant } & $1.9800 * *$ & $6.7036^{* *}$ & $6.7836^{* *}$ \\
\hline & (105.28) & (33.78) & (34.09) \\
\hline \multirow[t]{2}{*}{ EM } & $-0.0057 * *$ & $-0.0040 * *$ & $-0.0268 * *$ \\
\hline & $(-3.64)$ & $(-2.74)$ & $(-4.83)$ \\
\hline \multirow[t]{2}{*}{ Debt Ratio } & & $-1.1306^{* *}$ & $-1.1193 * *$ \\
\hline & & $(-19.49)$ & $(-13.42)$ \\
\hline \multirow[t]{2}{*}{ Size } & & $-0.2550 * *$ & $-0.2607 * *$ \\
\hline & & $(-19.49)$ & $(-19.85)$ \\
\hline \multirow[t]{2}{*}{ Growth } & & $-0.0656^{* *}$ & -0.0333 \\
\hline & & $(-2.05)$ & $(-1.01)$ \\
\hline \multirow[t]{2}{*}{ EM x CG } & & & $0.0326 * *$ \\
\hline & & & $(4.25)$ \\
\hline F-statistics & $13.27 * *$ & $217.43 * *$ & $217.43 * *$ \\
\hline Adjusted $\mathbf{R}^{2}$ & 0.0024 & 0.1439 & 0.1467 \\
\hline
\end{tabular}

Notes: Number in parenthesis is t-stat ** indicate significant at $5 \% *$ indicate significant at $10 \%$. 
For general investors, the measurement of corporate governance may not be continuous as with the CG score, but rather in discrete form, as in the high or low group. Therefore, instead of using the CG score, each firm will be classified into a high-CG firm or low-CG firm. In each year, firms with a CG score above the median are classified as high-CG and those with a CG score below the median are classified as low-CG. Panel 1 of table 3 reports the effect of earnings management on firm value between high-CG and low-CG firms. As expected, the coefficient of earnings management for low-CG firms was -0.0074 , which is negative and significant. However, for high-CG firms, the coefficient was only -0.0010 , which is less much less negative and not significant at the convention level. Panel 2 of table 3 reports the results of the regression with the interaction term between earnings management and dummy for high-CG. The result is consistent with earlier, as the coefficient of earnings management was negative while the coefficient of interaction term was positive and significant. This means that the negative effect of earnings management was lower for firms in the high-CG group.

Table 3. The effect of earnings management between High-CG firms and Low-CG firms

\begin{tabular}{cccc}
\hline \multirow{2}{*}{ Coefficient } & \multicolumn{2}{c}{ Panel 1 } & Panel 2 \\
\cline { 2 - 4 } Constant & Low-CG & High-CG & $6.7269^{* *}$ \\
& $7.4373^{* *}$ & $(24.14)$ & $(33.89)$ \\
EM & $(24.76)$ & $\mathbf{- 0 . 0 0 0 9}$ & $\mathbf{- 0 . 0 0 8 7 ^ { * * }}$ \\
& $\mathbf{- 0 . 0 0 7 4 ^ { * * }}$ & $\mathbf{( - 0 . 5 7 )}$ & $\mathbf{( - 3 . 9 3 )}$ \\
Debt Ratio & $\mathbf{( - 3 . 1 0 )}$ & $-1.1634^{* *}$ & $-1.1270^{* *}$ \\
& $-0.9583^{* *}$ & $(-10.15)$ & $(-13.51)$ \\
Size & $(-7.99)$ & $-0.2322^{* *}$ & $-0.2566^{* *}$ \\
& $-0.3085^{* *}$ & $(-13.70)$ & $(-19.60)$ \\
Growth & $(-15.24)$ & $0.6365^{* *}$ & $-0.0574^{*}$ \\
& $-0.2061^{* *}$ & $(8.70)$ & $(-1.78)$ \\
EM x DHIGH & $(-5.39)$ & & $\mathbf{0 . 0 0 8 3 * *}$ \\
& & & $(\mathbf{2 . 8 1 )}$ \\
\hline F-statistics & & $134.59^{* *}$ & $175.76^{* *}$ \\
Adjusted R & & 0.1715 & 0.1450 \\
\hline
\end{tabular}

Notes: Number in parenthesis is t-stat ** indicate significant at $5 \% *$ indicate significant at $10 \%$.

From the previous literature, it was seen that corporate governance is a mechanism for reducing some managerial opportunism. With the separation between ownership and control, managers that may very small or none of the firm ownership may make decisions for their own private benefit rather than maximizing firm value (Fama and Jensen, 1983). Corporate governance is a mechanism for controlling these problems. Protecting the rights of shareholders, especially minority shareholders, is one component of corporate governance. Regarding the ASSET4 CG score, it has included many perspectives of corporate governance, such as board structure, compensation policy, board functions, management vision and strategy, as well as shareholders' rights.

Table 4 shows the results of the analysis using the shareholders rights compared to using the overall CG score reported earlier. The score on shareholders rights was calculated by the average score on the components related to shareholders' rights. The results of the statistical tests using shareholders rights instead of the overall CS score were quite similar. Firms with higher shareholder rights protection will be less vulnerable to managerial opportunism. Therefore, the effect of earnings management is less negative for firms with higher scores on shareholders rights.

Table 5 reports on additional tests on the model in order to ensure the robustness of the results. First, the data used in this paper were collected across various firms in the U.S. for many years. The effect of earnings management on firm value may vary year-by-year. Therefore, the regressions based on equation 3 were estimated year-by-year. Then, a test of significance of the regression coefficient was conducted by t-test based on Fama and MacBeth (1973). The figures are reported in table 5 and show the same results as discussed earlier.

Another robustness check was carried out by excluding the banking industry because this industry may have different characteristics from those of non-banking firms, for example, leverage and asset types. Therefore, the previous regression was re-examined by excluding all observations from the banking industry. There were 148 firm-year observations excluded and 5,005 firm-year observations left in the analysis. The regression analysis, excluding the banking industry, is reported in table 5. The results are also quite similar to those reported earlier. 
Table 4. The role of shareholder rights component of corporate governance

\begin{tabular}{|c|c|c|c|c|}
\hline \multirow{2}{*}{ Coefficient } & \multicolumn{2}{|c|}{ With Interaction Terms } & \multicolumn{2}{|c|}{ With High-CG Dummy } \\
\hline & Overall CG Score & Shareholder Rights & Overall CG Score & Shareholder Rights \\
\hline \multirow[t]{2}{*}{ Constant } & $6.7836^{* *}$ & $7.4780 * *$ & $6.7269^{* *}$ & $6.7195^{* *}$ \\
\hline & $(34.09)$ & $(36.88)$ & $(33.89)$ & $(33.84)$ \\
\hline \multirow[t]{2}{*}{ EM } & $-0.0268 * *$ & $-0.0317 *$ & $-0.0087 * *$ & $-0.0067 * *$ \\
\hline & $(-4.83)$ & $(-1.85)$ & $(-3.93)$ & $(-3.27)$ \\
\hline \multirow[t]{2}{*}{ Debt Ratio } & $-1.1193 * *$ & $-0.9979 * *$ & $-1.1270 * *$ & $-1.1299 * *$ \\
\hline & $(-13.42)$ & $(-12.07)$ & $(-13.51)$ & $(-13.54)$ \\
\hline \multirow[t]{2}{*}{ Size } & $-0.2607 * *$ & $-0.3106^{* *}$ & $-0.2566^{* *}$ & $-0.2560 * *$ \\
\hline & $(-19.85)$ & $(-23.06)$ & $(-19.60)$ & $(-19.55)$ \\
\hline \multirow[t]{2}{*}{ Growth } & -0.0333 & $0.2560^{* *}$ & $-0.0574 *$ & $-0.0650^{* *}$ \\
\hline & $(-1.01)$ & $(6.5)$ & $(-1.78)$ & $(-2.01)$ \\
\hline \multirow[t]{2}{*}{ EM $\times$ CG } & $0.0326 * *$ & $0.0467 *$ & & \\
\hline & $(4.25)$ & (1.68) & & \\
\hline \multirow[t]{2}{*}{ EM x DHIGH } & & & $0.0083 * *$ & $0.0054 *$ \\
\hline & & & $(2.81)$ & (1.87) \\
\hline F-statistics & $217.43 * *$ & $216.58^{* *}$ & $175.76^{* *}$ & $174.72 * *$ \\
\hline Adjusted $R^{2}$ & 0.1467 & 0.1732 & 0.1450 & 0.1443 \\
\hline
\end{tabular}

Notes: Number in parenthesis is t-stat ** indicate significant at $5 \% *$ indicate significant at $10 \%$.

Table 5. Additional test of the effect of earnings management

\begin{tabular}{cccc}
\hline Coefficient & Full Sample & Fama-MacBeth Regression & Exclude Banking \\
\hline Constant & $6.7836^{* *}$ & $7.5001^{* *}$ & $6.8846^{* *}$ \\
& $(34.09)$ & $(42.24)$ & $(32.82)$ \\
EM & $\mathbf{- 0 . 0 2 6 8 * *}$ & $\mathbf{- 0 . 1 1 4 7 * *}$ & $\mathbf{- 0 . 0 2 7 1 * *}$ \\
& $\mathbf{( - 4 . 8 3 )}$ & $\mathbf{( - 3 . 2 5 )}$ & $\mathbf{( - 4 . 7 8 )}$ \\
Debt Ratio & $-1.1193^{* *}$ & $-1.3396^{* *}$ & $-1.0990^{* *}$ \\
& $(-13.42)$ & $(-13.44)$ & $(-12.80)$ \\
Size & $-0.2607^{* *}$ & $-0.2942^{* *}$ & $-0.2677^{* *}$ \\
& $(-19.85)$ & $(-36.69)$ & $(-19.47)$ \\
Growth & -0.0333 & $0.2076^{* *}$ & -0.0369 \\
& $(-1.01)$ & $(4.76)$ & $(-1.10)$ \\
EM x CG & $\mathbf{0 . 0 3 2 6 * *}$ & $\mathbf{0 . 2 1 3 3 * *}$ & $\mathbf{0 . 0 3 3 0 * *}$ \\
& $\mathbf{( 4 . 2 5 )}$ & $\mathbf{( 1 0 . 7 9 )}$ & $\mathbf{( 4 . 2 3 )}$ \\
\hline
\end{tabular}

Notes: Number in parenthesis is t-stat ** indicate significant at $5 \% *$ indicate significant at $10 \%$.

In this paper, earnings management was measured by accrual-based earning managements based on Leuz et al. (2003). Jones (1991) has proposed the discretionary accruals to as the measurement of earnings management instead of using total accruals. Discretionary accruals are the difference between total accruals and expected accruals, whereas expected accruals are estimated by the following regression model.

$$
\text { Accrual }_{i}=\beta_{0} \frac{1}{\text { Asset }_{t-1}}+\beta_{1} \frac{\Delta R E V_{t}}{\text { Asset }_{t-1}}+\beta_{2} \frac{P P E_{t}}{\text { Asset }_{t-1}}+\varepsilon_{i t}
$$

where $R E V$ is total revenue and $P P E$ is gross property, plant, and equipment. Accrual is the total accrual scaled down by total assets at the beginning of the year. The residuals from the regression model in equation 5 are a part of accruals that cannot be explained by change in revenue or non-current assets. Jones (1991) estimated the above regression using time-series and used the residuals as discretionary accruals. However, estimating the above regression with time-series is under the assumption that the parameters were stable over time. DeFond and Jiambalvo (1994) estimated the above regression model by cross-sectional with all firms in the same industry and same period. Therefore, the earnings management used in the previous analysis was recomputed according to Jones' model but estimated cross-sectionally with all firms within each industry. However, the accruals were based on Leuz et al. (2003) so that they were comparable with previous estimations.

Table 6 reports the role of corporate governance in the relationship between earnings management and firm value, whereas absolute discretionary accruals were used instead of total accruals, as in table 2 and 3 . The results 
are also qualitatively similar. More discretionary accruals can lead to lower firm values. However, for the firms with better governance, this negative effect will be apparently lower. Therefore, all of this empirical evidences supports the role of corporate governance in reducing managerial opportunism in earnings management. Firms with lower CG scores face the negative effect of earnings management, whereas the negative effect of earnings management for firms with higher CG scores is insignificant.

Table 6. The effect of earnings management using discretionary accruals

\begin{tabular}{cccc}
\hline Coefficient & Model 1 & Model 2 & Model 3 \\
\hline Constant & $7.3643^{* *}$ & $7.3803^{* *}$ & $7.3771^{* *}$ \\
& $(35.27)$ & $(35.32)$ & $(35.33)$ \\
DA & $\mathbf{- 0 . 0 0 2 4}$ & $\mathbf{- 0 . 0 3 6 7 *}$ & $\mathbf{- 0 . 0 1 0 6 * *}$ \\
& $\mathbf{( - 1 . 2 9 )}$ & $\mathbf{( - 1 . 8 0 )}$ & $\mathbf{( - 2 . 5 5 )}$ \\
Debt Ratio & $-1.0374^{* *}$ & $-1.0339^{* *}$ & $-1.0333^{* *}$ \\
& $(-12.20)$ & $(-12.16)$ & $(-12.15)$ \\
Size & $-0.3019^{* *}$ & $-0.3028^{* *}$ & $-0.3026^{* *}$ \\
& $(-21.73)$ & $(-21.78)$ & $(-21.78)$ \\
Growth & $0.2179^{* *}$ & $0.0398^{* *}$ & $0.2176^{* *}$ \\
& $(5.47)$ & $(5.46)$ & $(5.46)$ \\
DAx CG & & $\mathbf{0 . 0 4 3 4}$ & $\mathbf{( 1 . 6 9 ) *}$ \\
DAx DHALF & & & $\mathbf{0 . 0 1 0 2 * *}$ \\
& & & $(\mathbf{2 . 2 1})$ \\
\hline F-statistics & $247.62^{* *}$ & $198.61^{* *}$ & $199.47^{* *}$ \\
Adjusted R & 0.1717 & 0.1719 & 0.1725 \\
\hline
\end{tabular}

Notes: Number in parenthesis is t-stat ** indicate significant at $5 \% *$ indicate significant at $10 \%$.

\section{Conclusion}

In general, firm managers can use accounting accruals to manage earning reports for their own benefits. This will deteriorate firm value and the effect of earnings management will be negative for firm value. However, some argue that managers can use accounting accruals as a signal in earning reports. From this perspective, earnings management can be positive for firm value. Corporate governance can play a crucial role in restraining managerial opportunism. Previous studies have documented that corporate governance can reduce the level of earning managements. However, if corporate governance is important for reducing the conflict of interests that may be negative for the firm's value, it should help to reduce only harmful earnings management, not beneficial management.

The results in this paper provide evidence to support the role of corporate governance in reducing harmful earnings management rather than beneficial earnings management. The evidence in this research shows that the effect of earnings management on firm value is less negative for good-governance firms. Firms with poor governance face the negative effect of earnings management because these firms are more vulnerable to managerial opportunism. However, the negative effect of good-governance firms is not significant at the convention level. Strong corporate governance can reduce managerial opportunism, and earnings management is more likely to be used in a beneficial way. This means that corporate governance provides a crucial role in reducing the negative effect of earnings management.

The accounting professions have discussed and improved accounting standards to provide more meaningful accounting figures and to reduce managerial discretions in the report of earnings. The evidence from this paper shows that managerial discretion, such as earnings management, is not actually unfavorable under the condition that there is a good corporate governance mechanism. If firms maintain good governance and shareholders rights are well-protected, they will be less vulnerable to opportunistic earnings management. In this case, earnings management will be used in a favorable way, for example, to reduce earnings volatility or to convey information about future earnings by managers. Therefore, encouraging good governance is as important as improving accounting rules and standards.

\section{References}

Baker, T., Reitenga, A., \& Collins, D. (2003). Stock option compensation and earnings management incentives. Journal of Accounting, Auditing \& Finance, 18(4), 583-593. 
Bergstresser, D., \& Philippon, T. (2006). CEO incentives and earnings management. Journal of Financial Economics, 80(3), 511-529. http://dx.doi.org/10.1016/j.jfineco.2004.10.011

Cornett, M. M., McNutt, J. J., \& Tehranian, H. (2009). Earnings Management at Large U.S. Bank Holding Companies. Journal of Corporate Finance, 15, 412-430. http://dx.doi.org/10.1016/j.jcorpfin.2009.04.003

DeFond, M. L., \& Jiambalvo, J. (1994). Debt covenant violation and manipulation of accruals. Journal of Accounting and Economics, 17(1-2), 145-176. http://dx.doi.org/10.1016/0165-4101(94)90008-6

DeFond, M., Hung, M., \& Trezevant, R. (2007). Investor protection and the information content of annual earnings announcements: International evidence. Journal of Accounting and Economics, 43(1), 37-67. http://dx.doi.org/10.1016/j.jacceco.2006.09.001

Dutta, S., \& Gigler, F. (2002). The effect of earnings forecasts on earnings management. Journal of Accounting Research, 40(3), 631-655. http://dx.doi.org/10.1111/1475-679X.00065

Fama, E. F., \& Jensen, M. C. (1983). Separation of Ownership and Control. Journal of Law and Economics, 26(2), 301-325. http://dx.doi.org/10.1086/467037

Gompers, P., Ishii, J., \& Metrick, A. (2003). corporate governance and equity prices. Quarterly Journal of Economics, 118(1), 107-156. http://dx.doi.org/10.1162/00335530360535162

Hazarika, S., Karpoff, J. M., \& Nahata, R. (2012). Internal corporate governance, CEO turnover, and earnings management. Journal of Financial Economics, 104, 44-69. http://dx.doi.org/10.1016/j.jfineco.2011.10.011

Healy, P. M. (1985). The effect of bonus schemes on accounting decisions. Journal of Accounting and Economics, 7(1-3), 85-107. http://dx.doi.org/10.1016/0165-4101(85)90029-1

Jensen, M. C., \& Meckling, W. H. (1976). Theory of the firm: Managerial behavior, agency costs and ownership structure. Journal of Financial Economics, 3(4), 305-360. http://dx.doi.org/10.1016/0304-405X(76)90026-X

Johnson, S., Boone, P., Breach, A., \& Friedman, E. (2000). Corporate governance in the Asian financial crisis. Journal of Financial Economics, 58(1-2), 141-186. http://dx.doi.org/10.1016/S0304-405X(00)00069-6

Jones, J. J. (1991). Earnings management during import relief investigations. Journal of Accounting Research, 29(2), 193-228. http://dx.doi.org/10.2307/2491047

Kuang, Y. F. (2008). Performance-vested stock options and earnings management. Journal of Business Finance and Accounting, 35, 1049-1078. http://dx.doi.org/10.1111/j.1468-5957.2008.02104.x

La Porta, R., Lopez-de-Silanes, F., Shleifer, A., \& Vishny, R. W. (1998). Law and finance. Journal of Political Economy, 106(6), 1113-1155. http://dx.doi.org/10.1086/250042

La Porta, R., Lopez-de-Silanes, F., Shleifer, A., \& Vishny, R. W. (2000). Investor protection and corporate $\begin{array}{lllll}\text { governance. Journal of } & \text { Financial }\end{array}$ http://dx.doi.org/10.1016/S0304-405X(00)00065-9

Leuz, C., Nanda, D., \& Wysocki, P. D. (2003). Earnings management and investor protection: an international $\begin{array}{llll}\text { comparison. Journal of Financial } & \text { Economics, }\end{array}$ http://dx.doi.org/10.1016/S0304-405X(03)00121-1

Wang, J. L., Sheu, H. J., \& Chung, H. (2011). Corporate governance reform and earnings management. Investment Management and Financial Innovations, 8(4), 109-118. 